\title{
THE IMPACT OF CHEMICAL AND BIOLOGICAL CONTROL FOR COMMON BEAN PESTS, TETRANYCHUS URTICAE \&T.CUCRBITACEARUM
}

\author{
WAHBA, B.S. \\ Plant Protection Research Institute, ARC, Dokki, Giza, Egypt.
}

(Manuscript received $1^{\text {st }}$ February 2015)

\begin{abstract}
$\mathrm{F}$ ield studies were carried out to determine the effect of two pesticides, Ortus \&Kanemite and also two predacious mites released, Phytoseiulus persimilis (Athias-Henriot) and Amblyseius gossypii ( El-Badry) against the phytophagous mites, Tetranychus urticae Koch, and T.cucurbitacearum (Sayed) which attack common beans, paulista variety in Hoticultural Research Station in Al Kanater El- Khairiya, Qualiobeya Governorate throughout 2012 and 2013 seasons. The application of the acaricide, Kanemite shown better than the other,ortus to reduce the population density of the spider mite, $T$. urticae, eggs and mobile stages throughout two seasons,2012 and 2013 by occurance higher reduction percent to eggs and mobil stages. This result led to having green pods yield higher for kanemite treatment than ortus treatment in the previous mentioned seasons. The application of acaricides, kanemite and ortus contributed better effect than check to control two species of spider mites. The predators were released by bean leaflets harboring the predator individuals. The predator, $P$. persimilis had a higher effect comparing to the second predator, A. gossypii . This is reversed on the yield by occurance green pods yield higher for the treatment, P.persimilis than the other treatment,A.gossypii throughout 2012 and 2013 seasons.

The release of $P$. persimilis and $A$. gossypii revealed better effect than the check to the phytophagous mites, Tetranychus urticae Koch, and T.cucurbitacearum (Sayed).

Key words: bean-paulista-acaricides-ortus-kanemite-predator mites-P.persimilis-A.gossypir phytophagous mites- Tetranychus urticae - T.cucurbitacearum.
\end{abstract}

\section{INTRODUCTION}

Bean,phaseolus vulgaris $L$. is one of the important vegetable legume crops cultivated in Egypt which consume as dry seeds and or vegetable pods throughout the local market and exportation. These plants are infested difficult pest to manage on bean. This mite become a major problem because of the excessive use of 
pesticides,these kill not only two spotted spider mite, T.urticae,but also making environmental pollution. Pesticides use results in the development of strains of that are highly resistant to almost all classes of pesticides. In addation,chemical control of is highly restricted in Egypt because of increasing cancer over pesticides residues on fruits which are consumed fresh without removal of the skin. So we must using it in suitable time and limited doses.Fortunately, the predator mite, phytoseiulus persimilis A.-H,is now available for control of on bean in Egypt.Port and Scopes (1981) showed that small numbers of p.persimilis could control TSM on strawberries in walk - in plastic tunnels in Southern England.However, it was necessity to reduce over wintering populations of $T$. urticae by introducing predators in Autumn.Cross(1984) showed that introductions of predatory mites in March or early April at rate of one mite per plant were consistently successful. Batlaglia et al (1990) studied the biological control to two spotted spider mite, T.urticae by p.persimilis on strawberry in green house in Metapontum area of Italy in 1988-1989. Different predator mite species were released by several authors to control this pest on certain plants instead of acaricides as reported by ( Manjunantha et al. 1999, Mallik et al. 1999, Heikal \& Fawzy 2003, Abdalla et al. 2003 and Fawzy et al. 2006).

The present study was conducted the effectiveness of releasing predator mites, Phytoseiulus persimilis and Amblyseius gossypii as biological control and acaricides,Kanemite and Ortus as chemical control to suppress the population of the phytophagous mites, T. urticae and T. cucurbitacearum on bean.

\section{MATERIALS AND METHODS}

Seeds of bean, Paulista variety were planted on the $1^{\text {st }}$ of March in two successive years 2012 and 2013 in the Horticultural Research Station at Kanater El- Khairiya, Qualiobeya Governorate.

An area of about $97.2 \mathrm{~m}^{2}$ was divided into three replicates for each treatment and each replicate consisted of two lines with $3 \mathrm{~m}^{2}$ long and $0.6 \mathrm{~m}$ wide .Sampling of 10 leaflet per plot were randomly picked and placed directly into paper bags and transferred to the laboratory for examination. The pests and their eggs were recorded after 45 and 50 days of planting for chemical and biocontrol treatments when the foliage of plants became suitable. The applied chemical control treatments (acaricides) were

1- Kanemite $15 \mathrm{SC}$ at the rate $100 \mathrm{ml} / 100 \mathrm{~L}$ water.

2- Ortus super at the rate $50 \mathrm{~cm}^{3} / 100 \mathrm{~L}$ water. 
These compounds were applied at low volume sprays at the rate of $100 \mathrm{~L}$. of spray solution per feddan and done once on April $15^{\text {th }}$ and $13^{\text {th }}$

For two seasons respectively. samples for examination of the spider mites eggs and mobile stages were taken just before acaricide application and after one, three, five, seven, ten and fourteen days from application. Each sample consisted of ten leaflet from each replicate, and thrity leaflet for each treatment.Each leaflet was inspected on their upper and lower surface.

Individuals of the two predators were obtained from their mass rearing on spider mites T. urticae Koch on bean plants Phaseolus vulgaris (L.) in a laboratory of the Plant Protection Research Institute. The predator individuals were released on April $19^{\text {th }}$ and $20^{\text {th }}$ for the two seasons respectively when each plant host of $5-7$ true leaves. The predator release was carried out with bean leaflet harboring the predator $10-12$ individuals per leaflet. Randomized samples of 10 bean leaflets per replicate were investigated just before the predator release to record the number of movable stages of $T$. utricle and T. cucurbitacearum as precount, while post counts were undertaken weekly until the harvest.

Percentage of reduction in mite population for each Acaricides and predators were calculated according to Henderson and Tilton equation (1955)

\section{Statistical analysis}

Statistical analysis for ANOVA was carried out by using SAS 9.3.1 portable. Whereas the means were compared through LSD tests, least significant differences at $\mathrm{p}: 0.05$ level.

\section{RESULTS AND DISCUSSION}

Table (1\&3) shown the application of acaricides, ortus and kanemite In the first year of study, they referred to the reduction percentage which were highly effect after 24 hour on two spotted spider mites, Tetranychus urticae and T.cucurbitacearum,egg and mobil stages when they infested bean plants,paulista variety compared with control by recording $95.71,93.94,99.46$ and $99.66 \%$ reduction to $T$. urticae and T.cucurbitacearum,eggs respectively by the acaricides, Ortus and Kanemite respectively and $98.75,98.23,97.91$ and $96.81 \%$ reduction to mobile stages of the same two species of Acarine resp. by the previous mentioned of two Acaricides respectively. After a period of time the reduction percent decreased gradually to reach after fourteen days $73.20,72.56,85.87$ and $81.935 \%$ reduction to $T$. urticae and T.cucurbitacearum,eggs respectively by treatments, Ortus and Kanemite respectively and $80.90,82.27,94.34$ and $91.32 \%$ reduction to T. urticae and T.cucurbitacearum 
mobil stages by the same Acaricides resp.Also,we can notice that the treatment, Kanemite is better than the treatment,Ortus in their reduction with mean 82.53 and $82.27 \%$ to T.urticae, eggs and mobiles resp. while the Ortus treatment were 82.30 and $80.90 \%$ reduction at the same stages resp.

Statistical analysis show significant differences between inspections.

This data was agreement with Adel A.Abou El-Ela(2014) he recorded that the acaricide, Ortus led to reduce the populations of T.urticae moving stages with mean $80.62 \%$ during 2007 season on the early seedling time.

In the second year, table (2\&4) revealed the reduction percent of $T$. urticae and T.cucurbitacearum,eggs and mobile stages by the previous mentioned of Acaricides which were the highest after 24 hour compared with any other inspection and related with $97.13,97.36,81.55$, and $82.70 \%$ reduction to T. urticae and T.cucurbitacearum, eggs respectively by treatments, Ortus and Kanemite respectively and 95.05, 95.30, 75.13 and $73.54 \%$ reduction to T. urticae and T.cucurbitacearum mobile stages by the same acaricides resp. reduction percentage decreased gradually to reach 76.07 , $75.83,62.42$ and $59.14 \%$ reduction to T.urticae and T.cucurbitacearum,eggs respectively and $82.84,82.79,63.76$ and $55.94 \%$ reduction to T.urticae and T.cucurbitacearum mobile stages resp. by the same acaricides respectively.

Statistical analysis of data demonstrated significant differences between inspections each eggs and mobile stages.

\section{The effect on the yield}

Table (5) revealed relationship between plants treated with acaricides and resultant yield throughout 2012 and 2013 seasons and recorded acaricide treatment,kanemite the highest weight of green pods, 600.00 and $635.00 \mathrm{Kg} / \mathrm{fed}$. Throughout two seasons respectively. On the other hand, check plants related with the least weight of green pods by recording 160.00 and $185.00 \mathrm{~kg} / \mathrm{fed}$. For the same mentioned seasons resp. while the plants of acaricide, Ortus had moderate weight of green pods (548.33 and 595.00) $\mathrm{kg} / \mathrm{fed}$. For the same seasons resp. Statistical analysis of data show insignificant differences between acaricide treatments and significant to check.

Data shown in table (6\&8) the reduction percent to $T$. urticae, egg and mobile stages were higher by phytoseiid mite, p.persimilis than the other, A.gossypii with mean 57.50 and $51.11 \%$ reduction to eggs in 2012 and 2013 seasons respectively.

And 58.17 and $56.47 \%$ reduction to mobile stages in the same seasons resp. while, the reduction percent to $T$.urticae, eggs by A.gossypii were 50.83 and $42.29 \%$ reduction in the same mentioned seasons resp. and 44.33 and $50.96 \%$ reduction to mobiles at the same previous seasons resp. this data agreement with PICKETT C.H. 
and GILSTRAP(1986), they recorded that P.persimilis and Amblyseius californicus when fed on Tetanychid, oligonychus pratensis led to reduce to pest densities to $60 \%$ and $28 \%$ resp.

Data tabulated in table (7\&9) show the same trend of reduction percent by phytoseiid mite, p.persimilis to the phytophagous mite, T.cucurbitacearum,egg \& motel stages and were higher than the other, A.gossypii ; whereas, recorded 46.57 and $33.77 \%$ reduction to eggs in 2012 and 2013 seasons resp. and $70.68 \& 69.30 \%$ reduction to motel stages throughout the same seasons resp. while the reduction percent to T.cucurbitacearum,eggs and motil by A.gossypii were 17.57 and $33.76 \%$ reduction to eggs and 16.83 and $64.73 \%$ reduction to motel in the same mentioned seasons resp.

\section{The effect on the yield}

Data in table (10) revealed the means of green pod yields resultant from planting bean,paulista variety in the first March and released by two phytoseiid mite, p.persimilis and A.gossypii throughout 2012-2013 seasons.Treatment, p.persimilis recorded the highest weight of green pods 425.00 and $555.00 \mathrm{~kg} / \mathrm{fed}$. In two seasons respectively being significantly higher than check in two season seasons resp.

Treatment, A.gossypii revealed less weight of green pods 343.33 and 468.33 $\mathrm{kg} /$ fed. Being insignificantly lower than the previous treatment and higher the other treatment (check).

Check is the lowest weight and recorded 253.33 and $335.00 \mathrm{~kg} / \mathrm{fed}$.of green pods throughout the same seasons resp. being significantly lower than the remaining treatments except for their related to treatment,A.gossypii insignificant lower during second season only.

\section{CONCLUSION}

The present study aimed to reach suitable control programs for controlling the important sap-sucking pests infesting bean plants(Tetranychus urticae Koch, and T.cucurbitacearum Sayed) by using chemical and biological control which planting on March, $1^{\text {st }}$ throughout 2012 and 2013 seasons in Hoticultural Research Station in Al Kanater El- Khairiya, Qualiobeya Governorate. acaricide,Kanemite related to the best application to reduce the population density of the pests and give high yield of green pods compared with control. Also, phytoseiid mite, p.persimilis when released on April, $19^{\text {th }}$ and $20^{\text {th }}$ during the previous two seasons demonstrated high effect on populations of the pests and give high yield of green pods. 
Table 1 .The reduction percent of the two acaricides on the population density of T.urticae and.T.Cucurbitacearum infesngting bean plant during 2012

\begin{tabular}{|c|c|c|c|c|c|c|c|c|}
\hline \multirow{3}{*}{ inspections } & \multicolumn{4}{|c|}{ T.urticae } & \multicolumn{4}{|c|}{ T.Cucurbitacearum } \\
\hline & \multicolumn{2}{|c|}{ Ortus } & \multicolumn{2}{|c|}{ Kanemite } & \multicolumn{2}{|c|}{ Ortus } & \multicolumn{2}{|c|}{ Kanemite } \\
\hline & Egg & Mob. & Egg & Mob. & Egg & Mob. & Egg & Mob. \\
\hline After day & 95.71 & 98.75 & 93.94 & 98.23 & 99.46 & 97.91 & 99.66 & 96.81 \\
\hline After 3 day & 86.52 & 85.75 & 85.99 & 91.33 & 99.29 & 96.62 & 99.48 & 91.78 \\
\hline After 5 day & 84.25 & 79.07 & 83.20 & 86.63 & 94.86 & 94.55 & 94.08 & 90.75 \\
\hline After 7 day & 77.74 & 77.66 & 82.52 & 77.47 & 92.48 & 93.49 & 89.57 & 90.06 \\
\hline After 10 day & 76.38 & 76.63 & 76.97 & 72.85 & 88.28 & 92.06 & 86.13 & 89.74 \\
\hline After 14 day & 73.20 & 67.53 & 72.56 & 67.08 & 85.87 & 91.39 & 81.93 & 88.80 \\
\hline Mean & 82.30 & 80.90 & 82.53 & 82.27 & 93.37 & 94.34 & 91.81 & 91.32 \\
\hline L.S.D. & 10.07 & 14.39 & 10.07 & 14.39 & 8.32 & 3.49 & 8.32 & 3.49 \\
\hline
\end{tabular}

Table 2.The reduction percent of the two acaricides on the population density of T.urticae and.T.Cucurbitacearum infesngting bean plant during 2013 .

\begin{tabular}{|c|c|c|c|c|c|c|c|c|}
\hline \multirow{2}{*}{ inspections } & \multicolumn{4}{|c|}{ T.urticae } & \multicolumn{4}{c|}{ T.Cucurbitacearum } \\
\cline { 2 - 9 } & \multicolumn{2}{|c|}{ Ortus } & \multicolumn{2}{c|}{ Kanemite } & \multicolumn{3}{c|}{ Ortus } & \multicolumn{2}{c|}{ Kanemite } \\
\cline { 2 - 9 } & Egg & Mob. & Egg & Mob. & Egg & Mob. & Mob. \\
\hline After day & 97.13 & 95.05 & 97.36 & 95.30 & 81.55 & 75.13 & 82.70 & 73.54 \\
\hline After 3 day & 90.21 & 93.95 & 93.99 & 95.01 & 80.33 & 68.32 & 81.90 & 62.55 \\
\hline After 5 day & 89.82 & 92.26 & 92.58 & 94.64 & 76.92 & 66.06 & 80.67 & 58.54 \\
\hline After 7 day & 86.84 & 91.42 & 91.48 & 91.69 & 75.60 & 65.78 & 75.22 & 57.35 \\
\hline After 10 day & 80.83 & 84.23 & 85.69 & 89.32 & 71.77 & 64.25 & 64.29 & 56.12 \\
\hline After 14 day & 76.07 & 82.84 & 75.83 & 82.79 & 62.42 & 63.76 & 59.14 & 55.94 \\
\hline Mean & 86.82 & 89.96 & 89.49 & 91.46 & 74.77 & 67.22 & 73.99 & 60.67 \\
\hline L.S.D. & 9.75 & 6.43 & 9.75 & 6.43 & 11.09 & 7.23 & 11.09 & 7.23 \\
\hline
\end{tabular}


Table 3. The effect of the two acaricides on the population density of T.urticae and T.cucurbitacearum infesting bean plant in 2012

\begin{tabular}{|c|c|c|c|c|c|c|c|c|c|c|c|c|}
\hline \multirow{3}{*}{ inspections } & \multicolumn{6}{|c|}{ T.urticae } & \multicolumn{6}{|c|}{ T.Cucurbitacearum } \\
\hline & \multicolumn{2}{|c|}{ Ortus } & \multicolumn{2}{|c|}{ Kanemite } & \multicolumn{2}{|c|}{ Control } & \multicolumn{2}{|c|}{ Ortus } & \multicolumn{2}{|c|}{ Kanemite } & \multicolumn{2}{|c|}{ Control } \\
\hline & Egg & Mob. & Egg & Mob. & Egg & Mob. & Egg & Mob. & Egg & Mob. & Egg & Mob \\
\hline أبريل-15 & 19.93 & 8.00 & 16.33 & 8.69 & 12.43 & 8.50 & 7.80 & 1.63 & 8.27 & 1.60 & 6.80 & 1.23 \\
\hline أبريل-20 & 1.00 & 0.13 & 1.13 & 0.20 & 14.20 & 11.07 & 0.06 & 0.06 & 0.04 & 0.90 & 9.73 & 2.17 \\
\hline أبريل-22 & 3.37 & 1.77 & 2.87 & 1.17 & 15.59 & 13.20 & 0.90 & 0.13 & 0.07 & 0.31 & 11.07 & 2.90 \\
\hline أبريل-24 & 5.00 & 3.17 & 4.37 & 2.20 & 19.80 & 16.09 & 0.90 & 0.33 & 1.10 & 0.55 & 15.27 & 4.57 \\
\hline أبريل-26 & 6.87 & 3.47 & 5.07 & 3.80 & 22.08 & 16.50 & 1.70 & 0.50 & 2.50 & 0.75 & 19.70 & 5.80 \\
\hline أبريل-29 & 10.30 & 3.97 & 8.23 & 5.01 & 27.20 & 18.05 & 3.37 & 0.67 & 4.23 & 0.85 & 25.07 & 6.37 \\
\hline مايو-03 & 12.43 & 6.60 & 10.43 & 7.27 & 28.93 & 21.60 & 5.01 & 0.90 & 6.79 & 1.15 & 30.90 & 7.89 \\
\hline Mean & 8.41 & 3.87 & 6.92 & 4.05 & 20.03 & 15.00 & 2.82 & 0.60 & 3.29 & 0.87 & 16.93 & 4.42 \\
\hline L.S.D. & 6.78 & 3.93 & 6.78 & 3.93 & 6.78 & 3.93 & 6.33 & 1.63 & 6.33 & 1.63 & 6.33 & 1.63 \\
\hline
\end{tabular}

Table 4.The effect of the two acaroids on the population density of T.urticae and T.cucurbitacearum infesting bean plant in 2013

\begin{tabular}{|c|c|c|c|c|c|c|c|c|c|c|c|c|}
\hline \multirow{3}{*}{ inspections } & \multicolumn{6}{|c|}{ T.urticae } & \multicolumn{6}{|c|}{ T.Cucurbitacearum } \\
\hline & \multicolumn{2}{|c|}{ Ortus } & \multicolumn{2}{|c|}{ Kanemite } & \multicolumn{2}{|c|}{ Control } & \multicolumn{2}{|c|}{ Ortus } & \multicolumn{2}{|c|}{ Kanemite } & \multicolumn{2}{|c|}{ Control } \\
\hline & Egg & Mob. & Egg & Mob. & Egg & Mob. & Egg & Mob. & Egg & Mob. & Egg & Mob. \\
\hline 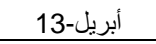 & 5.77 & 17.87 & 6.27 & 10.77 & 4.67 & 5.38 & 3.10 & 0.50 & 3.47 & 0.47 & 2.03 & 0.22 \\
\hline أبريل-21 & 0.17 & 1.17 & 0.17 & 0.67 & 4.80 & 7.12 & 0.60 & 0.13 & 0.63 & 0.13 & 2.13 & 0.23 \\
\hline أبريل-23 & 0.75 & 1.60 & 0.50 & 0.82 & 6.20 & 8.33 & 0.67 & 0.18 & 0.69 & 0.20 & 2.23 & 0.25 \\
\hline أبريل-25 & 0.97 & 2.15 & 0.76 & 0.95 & 7.63 & 8.85 & 0.80 & 0.27 & 0.75 & 0.31 & 2.27 & 0.35 \\
\hline 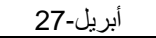 & 1.28 & 2.57 & 0.90 & 1.50 & 7.87 & 9.02 & 0.95 & 0.35 & 1.08 & 0.41 & 2.55 & 0.45 \\
\hline أبريل-30 & 1.90 & 4.90 & 1.54 & 2.02 & 8.02 & 9.45 & 1.25 & 0.39 & 1.77 & 0.45 & 2.90 & 0.48 \\
\hline مايو -04 & 2.67 & 5.74 & 2.93 & 3.47 & 9.03 & 10.07 & 1.75 & 0.42 & 2.13 & 0.48 & 3.05 & 0.51 \\
\hline Mean & 1.93 & 5.14 & 1.87 & 2.88 & 6.89 & 8.32 & 1.30 & 0.32 & 1.50 & 0.35 & 2.45 & 0.36 \\
\hline L.S.D. & 2.15 & 4.58 & 2.15 & 4.58 & 2.15 & 4.58 & 0.92 & 0.15 & 0.92 & 0.15 & 0.92 & 0.15 \\
\hline
\end{tabular}


Table 5. The effect of acaricides on the green pod crops of bean plant during 2012\&2013

\begin{tabular}{|c|c|c|c|c|c|c|}
\hline & \multicolumn{3}{|c|}{ weight of green pods/fed. } & \multicolumn{3}{|c|}{ weight of green pods/fed. } \\
\hline \multicolumn{4}{|c|}{ The first season } & \multicolumn{3}{|c|}{ The sound season } \\
\hline & Kanemite & Ortus & control & Kanemite & Ortus & control \\
\hline & 560.00 & 490.00 & 120.00 & 590.00 & 550.00 & 150.00 \\
\hline & 650.00 & 600.00 & 200.00 & 690.00 & 645.00 & 230.00 \\
\hline & 590.00 & 555.00 & 160.00 & 625.00 & 590.00 & 175.00 \\
\hline Mean & 600.00 & 548.33 & 160.00 & 635.00 & 595.00 & 185.00 \\
\hline LSD. & \multicolumn{3}{|c|}{94.83} & \multicolumn{3}{|c|}{112.18} \\
\hline
\end{tabular}

Table 6. The effect of P. persimilis and A . Gossypii on the population density of T. urticae infesting bean plants through 2012 season .

\begin{tabular}{|c|c|c|c|c|c|c|c|c|c|c|}
\hline \multirow{3}{*}{ inspections } & \multicolumn{4}{|c|}{ P.persimilis } & \multicolumn{4}{|c|}{ A.gossypii } & \multicolumn{2}{|c|}{ Control } \\
\hline & \multicolumn{4}{|c|}{ T.urticae } & \multicolumn{4}{|c|}{ T.urticae } & \multicolumn{2}{|c|}{ T.urticae } \\
\hline & Egg & reduction $\%$ & Individual & reduction $\%$ & Egg & reduction $\%$ & Individual & reduction $\%$ & Egg & Individual \\
\hline أبريل-19 & 0.5 & - & 0.52 & & 0.45 & & 0.33 & & 0.30 & 0.50 \\
\hline أبريل-25 & 0.79 & 21 & 0.45 & 33 & 0.80 & 47 & 0.47 & 46 & 1.00 & 0.65 \\
\hline مايو-02 & 1.1 & 56 & 0.49 & 48 & 1.05 & 53 & 0.25 & 58 & 1.5 & 0.90 \\
\hline مايو-09 & 2.01 & 57 & 0.97 & 63 & 1.88 & 55 & 0.63 & 63 & 2.80 & 2.55 \\
\hline مايو-16 & 4.23 & 79 & 2.33 & 77 & 7.65 & 57 & 1.67 & 74 & 11.90 & 9.83 \\
\hline مايو-23 & 7.43 & 71 & 2.57 & 86 & 12.13 & 48 & 11.93 & 16 & 15.53 & 21.63 \\
\hline مايو-30 & 12.40 & 61 & 14.17 & 42 & 15.50 & 45 & 14.17 & 9 & 18.87 & 23.47 \\
\hline Mean & 4.07 & 57.50 & 3.07 & 58.17 & 5.64 & 50.83 & 4.21 & 44.33 & 7.41 & 8.50 \\
\hline L.S.D. & 7.06 & 18.68 & 8.32 & 30.5 & 7.06 & 18.68 & 8.32 & 30.5 & 7.06 & 8.32 \\
\hline
\end{tabular}


Table 7. The effect of P. persimilis and A . Gossypii on the population density of T. cucurbitacearum infesting bean plants through 2012 season .

\begin{tabular}{|c|c|c|c|c|c|c|c|c|c|c|}
\hline \multirow[t]{3}{*}{ inspections } & \multicolumn{4}{|c|}{ P.persimilis } & \multicolumn{4}{|c|}{ A.gossypii } & \multicolumn{2}{|c|}{ Control } \\
\hline & \multicolumn{4}{|c|}{ T.cucrbitacearum } & \multicolumn{4}{|c|}{ T.cucrbitacearum } & \multicolumn{2}{|c|}{ T.cucrbitacearum } \\
\hline & Egg & reduction\% & Individual & reduction $\%$ & Egg & reduction\% & Individual & reduction $\%$ & Egg & Individual \\
\hline أبريل-19 & 2.03 & & 0.47 & & 2.00 & . & 0.38 & 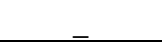 & 2.10 & 0.53 \\
\hline أبريل-25 & 2.67 & 30.95 & 0.63 & 26.76 & 3.40 & 10.75 & 0.61 & 12.29 & 4.00 & 0.97 \\
\hline مايو-02 & 1.97 & 52.93 & 0.13 & 88.46 & 3.13 & 24.1 & 0.75 & 17.63 & 4.33 & 1.27 \\
\hline مايو-09 & 1.27 & 81.57 & 0.21 & 88.16 & 4.73 & 30.34 & 1.05 & 26.78 & 7.13 & 2.00 \\
\hline مايو-16 & 3.77 & 50.82 & 1.37 & 78.63 & 6.35 & 15.92 & 4.05 & 21.87 & 7.93 & 7.23 \\
\hline مايو-23 & 7.13 & 35.69 & 2.93 & 73.71 & 9.55 & 12.58 & 7.75 & 14.01 & 11.47 & 12.57 \\
\hline مايو-30 & 13.67 & 27.48 & 3.85 & 68.38 & 16.53 & 10.99 & 9.02 & 8.37 & 19.50 & 13.73 \\
\hline Mean & 4.64 & 46.57 & 1.37 & 70.68 & 6.53 & 17.45 & 3.37 & 16.83 & 8.07 & 5.47 \\
\hline L.S.D. & 5.81 & 19.57 & 4.5 & 21.73 & 5.81 & 19.57 & 4.5 & 21.73 & 5.81 & 4.5 \\
\hline
\end{tabular}

Table 8. The effect of P. persimilis and A . Gossypii on the population density of T. urticae infesting bean plants through 2013 season .

\begin{tabular}{|c|c|c|c|c|c|c|c|c|c|c|}
\hline \multirow[t]{3}{*}{ inspections } & \multicolumn{4}{|c|}{ P.persimilis } & \multicolumn{4}{|c|}{ A.gossypii } & \multicolumn{2}{|c|}{ Control } \\
\hline & \multicolumn{4}{|c|}{ T.urticae } & \multicolumn{4}{|c|}{ T.urticae } & \multicolumn{2}{|c|}{ T.urticae } \\
\hline & Egg & reduction $\%$ & Individual & reduction\% & Egg & reduction $\%$ & Individual & reduction\% & Egg & Individual \\
\hline أبريل-20 & 4.93 & & 1.73 & & 4.50 & & 1.73 & & 4.67 & 1.37 \\
\hline أبريل-27 & 3.83 & 41.42 & 1.10 & 71.9 & 2.77 & 53.63 & 1.83 & 53.25 & 6.20 & 3.10 \\
\hline مايو-03 & 2.17 & 73.06 & 0.90 & 78.6 & 2.40 & 67.36 & 1.23 & 70.75 & 7.63 & 3.33 \\
\hline مايو-10 & 1.77 & 78.45 & 2.17 & 59.08 & 4.50 & 39.97 & 2.03 & 61.72 & 7.78 & 4.20 \\
\hline مايو-17 & 7.07 & 35.6 & 3.75 & 38.77 & 6.77 & 32.44 & 3.67 & 40.08 & 10.40 & 4.85 \\
\hline مايو-24 & 9.27 & 27.01 & 7.56 & 33.99 & 9.50 & 18.05 & 8.13 & 29.02 & 12.03 & 9.07 \\
\hline Mean & 4.84 & 51.11 & 2.87 & 56.47 & 5.07 & 42.29 & 3.10 & 50.96 & 8.12 & 4.32 \\
\hline L.S.D. & 3.4 & 30.90 & 3.17 & 26.62 & 3.4 & 30.90 & 3.17 & 26.62 & 3.4 & 3.17 \\
\hline
\end{tabular}


Table 9.The effect of P. persimilis and A . Gossypii on the population density of T. cucurbitacearum infesting bean plants through 2013 season .

\begin{tabular}{|c|c|c|c|c|c|c|c|c|c|c|}
\hline \multirow[t]{3}{*}{ inspections } & \multicolumn{4}{|c|}{ P.persimilis } & \multicolumn{4}{|c|}{ A.gossypii } & \multicolumn{2}{|c|}{ Control } \\
\hline & \multicolumn{4}{|c|}{ T.cucrbitacearum } & \multicolumn{4}{|c|}{ T.cucrbitacearum } & \multicolumn{2}{|c|}{ T.cucrbitacearum } \\
\hline & Egg & reduction $\%$ & Individual & reduction $\%$ & Egg & reduction $\%$ & Individual & reduction $\%$ & Egg & Individual \\
\hline أبريل-20 & 1.85 & _ & 0.27 & _- & 1.63 & - & 0.24 & - & 2.13 & 0.15 \\
\hline أبريل-27 & 1.73 & 10.68 & 0.26 & 48.41 & 1.43 & 16.2 & 0.21 & 53.13 & 2.23 & 0.28 \\
\hline مايو-03 & 1.73 & 30.51 & 0.22 & 65.08 & 1.68 & 32.9 & 0.25 & 55.36 & 2.27 & 0.35 \\
\hline مايو-10 & 0.51 & 75.84 & 0.07 & 89.49 & 0.56 & 69.89 & 0.03 & 94.93 & 2.43 & 0.37 \\
\hline مايو-17 & 2.03 & 43.41 & 0.29 & 61.64 & 1.91 & 39.57 & 0.25 & 62.8 & 4.13 & 0.42 \\
\hline مايو-24 & 3.50 & 8.42 & 0.33 & 60.99 & 3.07 & 10.25 & 0.32 & 57.45 & 4.47 & 0.47 \\
\hline Mean & 1.89 & 33.77 & 0.24 & 69.30 & 1.71 & 33.76 & 0.22 & 64.73 & 2.94 & 0.34 \\
\hline Mean & 1.17 & 37.36 & 0.12 & 25.04 & 1.17 & 37.36 & 0.12 & 25.04 & 1.17 & 0.12 \\
\hline
\end{tabular}

Table 10.The effect of the predaceous mites on the green pod crops of bean plant during 2012\& 2013

\begin{tabular}{|c|c|c|c|c|c|c|}
\hline & \multicolumn{3}{|c|}{ weight of green pods/fed. } & \multicolumn{3}{|c|}{ weight of green pods/fed. } \\
\hline \multicolumn{4}{|c|}{ The first season } & \multicolumn{2}{|l|}{ The second season } & \multirow{3}{*}{$\begin{array}{l}\text { control } \\
290.00\end{array}$} \\
\hline & A.gossypii & \multirow{2}{*}{$\begin{array}{c}\text { P.persimilis } \\
350.00 \\
\end{array}$} & \multirow{2}{*}{$\begin{array}{l}\text { control } \\
210.00\end{array}$} & A.gossypii & \multirow{2}{*}{$\begin{array}{c}\text { P.persimilis } \\
490.00\end{array}$} & \\
\hline & 290.00 & & & 410.00 & & \\
\hline & 400.00 & 500.00 & 300.00 & 520.00 & 625.00 & 375.00 \\
\hline & 340.00 & 425.00 & 250.00 & 475.00 & 550.00 & 340.00 \\
\hline Mean & 343.33 & 425.00 & 253.33 & 468.33 & 555.00 & 335.00 \\
\hline LSD. & \multicolumn{3}{|c|}{119.27} & \multicolumn{3}{|c|}{93.18} \\
\hline
\end{tabular}




\section{REFERENCES}

1. ADEL A. ABOU EL-ELA. 2014. Efficacy of five Acaricides against two spotted spider mite T. urticae Koch and their side effects on some natural enemies. J. Basic \& Appl. Zoology. 67(1) 2014,pp.13-18.

2. FATMA S. ALI AND M.M. EL-SAYED ET AL. 2003. Release of the two predatory mites, Phytoseiulus plumifer (C. \& F.) and Amblyseius swirskii (Athias-Henriot) against two citrus acarine pests. Bull. Ent. Soc. Egypt, Vol. $80: 133-146$.

3. PICKETT C.H., F.E. GISTRAP. 1986. predation of oligonychus pratensis by P.persimilis and Amblyseius californicus under control laboratory condations. Entomophaga 31,issue 2 ip 205-212.

4. CROSS, J.V. 1984. Biological contol of two spotted Tetranychus urticae Koch by phytoseiulus persimilis on strawberries grown in "walk-in" tunnel and a simplified method of spider mite population assessment.plant pathol. 33: 417-423.

5. FAWZY, M.M., K.M. EL-SAIDAE AND M.M. ELERKSOUSY. 2006. Evaluation of the predaceous mite, Phytoseiulus persimilis (A.- H.) release on peach and almond trees at North Sinai Governorate to control the two spider mites, T. urticae. J.Agric. Res. 84 (6) : 1811 -1817.

6. FAWZY, M.M., MONA S. EL-GHOBASHI AND N. ABDEL - WAHED. 2006. Biological Control of the two spotted spider mites, T. urticae. (Koch) by the phytoseiid mite, Phytoseiulus persimilis (A.- H.) in cantaloupe field in Sharkia Governorate (Acari : Tetranychidae). Egypt. J. Agric. Res. 84(2): 655 -362.

7. HEIKAL, I.H. AND M.M. FAWZY. 2003. A preliminary study of biological control of T. urticae ( Acari : Phytoseiidae \& Tetranychidae). Egypt. J. Agric. Res. 81 (1) : $93-100$

8. MANJUNANTHA, M. S.G. HANCHINAL AND S.V. KULKARNI. 1999. : Mass multiplication of predatory mites Amblyseius ovalis ( Phytoseiidae) and field release against yellow mites and thrips on Chilli. J Acarl. 14 ( 1 \& 2) : 16 - 21 .

9. MALLIK, B., R. VAIDYA AND M.H. KUMAR. 1999. Mass production of the predator, Amblyseius longspinosus ( Acari : Phytoseiidae) J Acarl. 15 ( 1 \& 2): $15-17$.

10. PORT,C.M. AND N.E.A. 1981. Biological control by predator mite (Phytoseiulus persimilis Athias-Henriot) to red spider mite (Tetranychus urticae Koch) infesting strawberry in walk-in plastic tunnels. Plant pathology 30:95-99. 


\title{
تاثير المكافحة الكيماوية والحيوية لآفتى الفاصوليا
}

\section{Tetranychus urticae \& T.cucurbitacearum}

\author{
باسم صبرى وهبه \\ معهز بحوث وقايه النباتات - مركز البحوث الزراعيه - الدقى - الجبزة
}

أظهرت النتائج الحقلية نوعين من المبيدات الاكاروسية Kanemite \& Ortus وكذلك أطلاق نوعين من المفترسات الاكاروسية Phytoseiulus persimilis (Athias-Henriot) and Amblyseius gossypii (El-Badry) Tetranychus urticae Koch, and الاكاروسات النباتية العنكبوت الاحمر ذات البقعتين T.cucurbitacearum (Sayed)

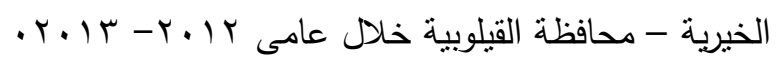
أظهر المبيد Kanemite أفضل من Ortus فى ارتفاع معدل الخفض للعنكبوت الاحمر لطور البيض

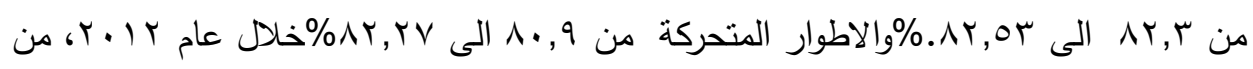
r,

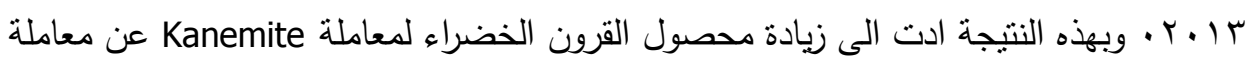
Ortus كما ارتبط كل من معاملتى المبيدات الاكاروسية بتاثير افضل من الكنترول (check) فى نقص اعداد

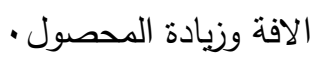
اطلاق المفترسات الاكاروسية تم بواسطة وريقات نباتات الفاصوليا وارتبط المفترس الاكاروسى

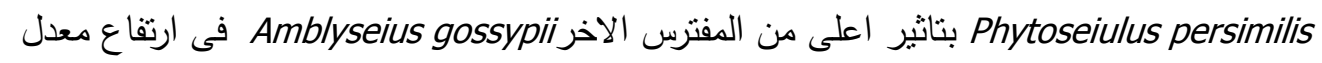

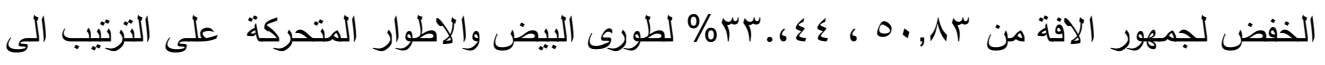
\% \% N, l V، OV,0

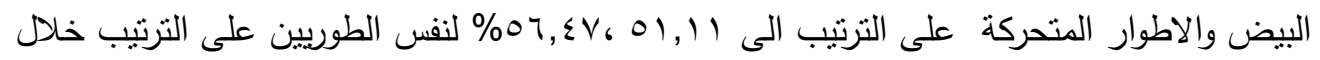

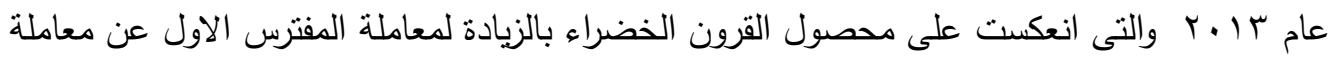

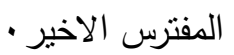
أظهر أطلاق المفترسات الاكاروسية السابقة الذكر تاثير افضل من الكنترول على كل من العنكبوت

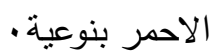

